\title{
Outcomes of Chronic Hepatitis B Virus Infection in Children: A 20-Year Follow-up
}

\author{
Nafiye Urgancl' (D, Derya Kalyoncu 2,3 (1) \\ 'Department of Pediatric gastroenterology, Șișli Hamidiye Etfal Training and Research Hospital, İstabul, Turkey \\ 2Department of Pediatrics, Șișli Hamidiye Etfal Training and Research Hospital, İstabul, Turkey \\ ${ }^{3}$ Department of Pediatrics, İstinye State Hospital, İstanbul, Turkey
}

ORCID IDs of the authors: N.U. 0000-0003-4854-507X; D.K. 0000-000I-8449-762I.

Cite this article as: Urgancı N, Kalyoncu D. Outcomes of Chronic Hepatitis B Virus Infection in Children: A 20-Year Follow-up. Cyprus J Med Sci 2019; 4(2): 77-83.

\section{BACKGROUND/AIMS}

The aim of the present study was to evaluate seroconversion rates in children with chronic hepatitis $\mathrm{B}(\mathrm{CHB})$ infection and determine the factors influencing the natural course of liver diseases.

\section{MATERIAL and METHODS}

A total of 458 hepatitis B surface antigen (HBsAg)-positive patients aged 0.75-17 years were tested for hepatitis markers, liver function tests, and hepatitis B virus (HBV) DNA levels at baseline and periodically at every 3 months following recruitment. Patients with CHB $(n=321)$ were divided into two groups: treated and untreated patients. The seroconversion rates between the two groups were compared, and their relationship with age, sex, vaccination status, coinfections, aminotransferases, HBV DNA levels, and cirrhosis was determined.

\section{RESULTS}

Hepatitis B e antigen ( $\mathrm{HBeAg}$ ) seroconversion rates were 30 in 97 patients 30/97 (30.9\%) in untreated patients and 67/147 (45.5\%) in treated patients $(p=0.023)$. HBsAg seroconversion rates were $10 / 174(5.7 \%)$ in untreated patients and $16 / 147(10.8 \%)$ in treated patients $(p=0.10)$. No significant difference was observed in $\mathrm{HBeAg}$ and $\mathrm{HBs} A g$ seroconversion times between the two groups $(p>0.05)$.

\section{CONCLUSION}

In our study, although the $\mathrm{HBeAg}$ seroconversion rate was significantly higher in treated patients than in untreated patients, the HBsAg seroconversion rate was not different between the groups.

Keywords: Children, chronic hepatitis B, cirrhosis, HBsAg, HBeAg, outcome

\section{INTRODUCTION}

Chronic hepatitis B virus (HBV) infection is a major cause of liver diseases associated with the development of cirrhosis and hepatocellular carcinoma (HCC). The natural course of HBV infection is greatly influenced by the age of the individuals at infection, host immune response to the virus, and the level of HBV replication (I). It The natural course of HBV infection comprises four phases: immune tolerance, immune clearance [hepatitis B e antigen (HBeAg)-positive chronic hepatitis $\mathrm{B}(\mathrm{CHB})$ ], low or non-replication (inactive carrier state), and reactivation ( $\mathrm{HBe} \mathrm{Ag}$-negative $\mathrm{CHB})(\mathrm{I}-3)$.

The risk factors associated with the loss of hepatitis B surface antigen (HBsAg) and/or HBeAg that can occur spontaneously or following treatment and the development of progressive liver inflammation, fibrosis, and cirrhosis remain unclear. Given that it is not certain that treatment with interferon (IFN) increases seroconversion rates and improves prognosis, the benefits of treatment (IFN, lamivudine) have not been established (4-6). The risk for cirrhosis and HCC is low; therefore, treatment is not recommended because of the development of viral resistance in carriers who are in the immune tolerance phase (6). However, children with $\mathrm{CHB}$ infection would require regular screening for the progression of infection to cirrhosis and HCC because some of them will subsequently have flares of hepatitis and develop HBeAg-positive immune active hepatitis or $\mathrm{HBeAg}$-negative active hepatitis $(5,6)$. 
The present study aimed to evaluate seroconversion rates in children with $\mathrm{CHB}$ infection and determine the factors influencing the natural course of liver diseases.

\section{MATERIAL and METHODS}

A total of $458 \mathrm{HBsAg}$-positive children who were admitted to the Division of Pediatric Gastroenterology of Sisli Hamidiye Etfal Training and Research Hospital (Istanbul, Turkey) between 1998 and 2018 were retrospectively evaluated. Data on vaccination status, duration of HBsAg positivity, type of onset (acute or chronic), mode of transmission, concomitant hepatitis $D$ virus (HDV) and/or hepatitis C virus ( $\mathrm{HCV}$ ) positivity, and physical examination signs (hepatomegaly, splenomegaly, and ascites) were obtained.

Complete blood count, biochemical tests, coagulation tests, HBsAg, antibody to hepatitis B surface antigen (anti-HBs), total antibody to hepatitis B core antigen (anti-HBc), antibody to hepatitis B e antigen (anti-HBeAg), anti-HCV, anti-HDV, and antibody to human immunodeficiency virus were examined in all patients using commercially available enzyme-linked immunoassays (Cobas Core, Roche Diagnostics, Pleasanton, CA, USA). HBV DNA and HCV RNA levels were measured using quantitative real-time polymerase chain reaction (COBAS TaqMan 48; Roche Diagnostics, Pleasanton, CA, USA). Liver biopsy was performed according to the Menghini technique. The stage and grade of liver involvement were scored according to Knodell's hepatic activity index ( $\mathrm{HAl})(7)$ in all treated patients. Children were followed up by testing $\mathrm{HBeAg}, \mathrm{HBs} A g, \mathrm{HBV}$ DNA, and liver function every 3 months for the first year and then annually. The study was approved by the Ethics Committee of the institution. Authors declared that the research was conducted according to the principles of the World Medical Association Declaration of Helsinki ' Ethical Principles for Medical Research Involving Human Subjects' (amended in October 2013).Informed consents were obtained from all the parents of the children before biopsy and other procedures.

Patients whose alanine aminotransferase (ALT) and aspartate aminotransferase levels were three times the upper normal limits at admission were regarded as acute onset patients. Patients whose HBsAg continued to be positive for $>6$ months, indicating chronic HBV infection, were included in the study. A total of 44 (9\%) patients who developed seroconversion during the first 6 months were regarded as acute hepatitis $B$ infection and those with fulminant hepatitis were excluded from the study. Of the $4 \mid 4 \mathrm{HBeAg}$-positive children, 93 were excluded because of incomplete patient data or were lost to follow-up.

Inactive carriers were defined as $\mathrm{HBeAg}$ negativity, anti-HBe, undetectable or low levels of HBV DNA $\left(<2000 \mathrm{IU} / \mathrm{mL}\right.$ or $10^{4}$ copies $/ \mathrm{mL}$ ), persistent normal levels of $A L T$, and inactive liver histology $(2,4)$. HBeAg-negative chronic hepatitis (mutant $\mathrm{HBV}$ infection/precore or core promoter mutant) is defined as $\mathrm{HBeAg}$ negativity with anti-HBe positivity, detectable serum HBV DNA levels (2000-20 million $\mathrm{IU} / \mathrm{mL}$ or $10^{4}-10^{8}$ copies $/ \mathrm{mL}$ ), increased $A L T$, and moderate or severe necroinflammation with variable amounts of fibrosis on liver biopsy (2).

$\mathrm{HBeAg}$ seroconversion was defined as loss of $\mathrm{HBeAg}$ and gain of anti-HBe antibody occurring either spontaneously or fol- lowing treatment. HBsAg seroconversion was defined as loss of HBsAg and gain of anti-HBsAg antibody. Reactivation was defined as an increase in ALT (more than twice the upper normal limit) with the reappearance of HBV DNA, with or without reversion to $\mathrm{HBeAg}$.

During follow-up, patients whose HBsAg, $\mathrm{HBeAg}$, and HBV DNA positivity persisted for $>6$ months, aminotransferase levels were twice the upper normal limit, who had liver biopsy, and in whom the other causes of liver diseases were excluded were started on treatment. Patients were treated with IFN alpha-2a or IFN alpha- $2 b$ (at a dose of 3-5 MU/m² three times a week for 6 months, subcutaneously) alone or in combination with lamivudine ( $4 \mathrm{mg} / \mathrm{kg} /$ day once daily for 12 months, orally). Response to treatment was defined as HBV DNA undetectability, loss of $\mathrm{HBeAg}$ with seroconversion to anti-HBe, and ALT normalization ( $A L T \leq$ Ix upper normal limit).

\section{Statistical Analysis}

Statistical analysis was performed using the Statistical Package for the Social Sciences version II.5 (SPSS Inc.; Chicago, IL, USA) software. All results are expressed as mean \pm SD. Statistical comparisons were made using the unpaired Student's t-test and Pearson correlation test. Qualitative variables were analyzed using Fisher's exact and chi-square tests. A p value of $<0.05$ was considered statistically significant.

\section{RESULTS}

The age of 32I patients with $\mathrm{CHB}$ of the $458 \mathrm{HBsAg}$-positive patients ranged from 0.75 to $17(8.99 \pm 3.75)$ years, and the maleto-female ratio was 3.1:2. The mean duration of follow-up was $15 \pm 4.7$ years. The mode of transmission was mostly $(60 \%)$ vertical (from mother to child), and $6 \%$ of the patients were vaccinated against hepatitis B. Although HBV immunoglobulin prophylaxis is used in Turkey to prevent the vertical transmission of $\mathrm{CHB}$, the patients recruited in the present study were those whose mothers have not been prenatally screened for HBV; therefore, such patients have not been given HBV immunoglobulin prophylaxis.

Overall, $75 \%$ of the patients were HBeAg positive. All the 4 patients with concurrent $\mathrm{HCV}$ infection had been infected with $\mathrm{HCV}$ via blood transfusion. None of the patients had a family history of HCC. The clinical characteristics and laboratory results of the patients have been summarized in Table I.

Of the 270 patients, $12.2 \%$ ( $n=33)$ were HBV DNA negative and $87.8 \%(n=237)$ were positive at admission. HBV DNA levels could not be analyzed in 51 patients because the parents could not charge the cost of the tests. Of the $237 \mathrm{HBV}$ DNA positive patients, $11 \%(n=26)$ were HBeAg negative, and these patients were regarded as mutant $\mathrm{HBV}$ infection ( $\mathrm{HBeAg}$-negative chronic hepatitis).

A mild correlation was observed between cirrhosis and HBsAg titer $(r=0.298, p<0.006)$. A significant correlation was observed between HDV $(n=4)$ and $\mathrm{HCV}(n=4)$ coinfections and cirrhosis $(r=0.666, p<0.000$ and $r=0.213, p<0.000$, respectively). No correlation was established among HBV DNA, HAl scores, and cirrhosis ( $r=0.130, p<0.112$ and $r=-0.046, p<0.447$, respectively). Similarly, no correlation was observed between HBV DNA and cirrhosis $(r=-0.046, p<0.447)$. The seroconversion rates between treat- 
ed and untreated patients and their relationship with age; sex; vaccination status; mode of transmission; physical examination signs; initial laboratory results; and HBsAg, $\mathrm{HBeAg}$, and HBV DNA titers are summarized in Table 2.

A total of 147 patients were treated with IFN alpha- $2 a(n=54)$, IFN alpha-2b $(n=48)$, IFN alpha-2b and lamivudine $(n=34)$, and IFN alpha-2a and lamivudine $(n=I I)$ during 6 months. The correlations among treatment modalities, and seroconversion rates are shown in Table 3.

\section{TABLE I. Clinical characteristics of the patients at admission}

Age (mean $\pm S D$, range years)

$\operatorname{Sex}(M / F)$ $8.99 \pm 3.75$ ( $0.75-17$ years $)$ 197/124 (3.1:2)

Mode of transmission

Mother

$194(60 \%)$

Father

$47(14 \%)$

Siblings $35(11 \%)$

Blood transfusion $32(10 \%)$

Surgical operation $7(2 \%)$

Other (tooth extraction, cousin vs) $6(1.86 \%)$

Hepatitis B vaccination

Yes

$302(94 \%)$

No $19(6 \%)$

$\mathrm{HBeAg}$ positivity

$24 \mathrm{I}(75 \%)$

Anti-HBe positivity $80(25 \%)$

Coinfection

HDV

$\mathrm{HCV}$ $4(1.24 \%)$

Splenomegaly

$10(3.1 \%)$

Hepatomegaly

$15(4.6 \%)$

Ascites

Cirrhosis

$5(1.5 \%)$

Biopsy

Yes

147

No

174

HAl score

Minimal

$23(16 \%)$

Mild

$68(46 \%)$

Moderate

35 (24\%)

Severe

Fibrosis stage

None

$13(9 \%)$

Minimal

91 (62\%)

Mild

$31(21 \%)$

Moderate

II (7\%)

Severe

I (0.6\%)

$\mathrm{HBeAg}$ : Hepatitis B e antigen; Anti-HBe: Hepatitis B e antibody; HDV: Hepatitis Delta virus; $\mathrm{HCV}$ : Hepatitis $C$ virus
Only 97 of the 174 untreated patients were HBeAg positive. $\mathrm{HBeAg}$ seroconversion rates were 30/97 (30.9\%) in untreated patients (spontaneous seroconversion) during $20.8 \pm 21.9$ months and $67 / 147(45.5 \%)$ in treated patients during $27.8 \pm 17.7$ months $(p=0.023$ ) (Figure 1). HBsAg seroconversion rates were 10/174 (5.7\%) in untreated patients (spontaneous seroconversion) during $13.9 \pm 12$ months and $16 / 147(10.8 \%)$ in treated patients during $26.5 \pm 11.9$ months $(p=0.10$ ). No significant difference was observed in $\mathrm{HBeAg}$ and $\mathrm{HBs} A g$ seroconversion times between the two groups ( $p>0.05)$. No difference was also observed with respect to $\mathrm{HBeAg}$ and $\mathrm{HBsAg}$ seroconversion rates between treatment with IFN alpha-2a or IFN alpha-2b alone and in combined treatment with lamivudine $(p=0.07$ and $p=0.64$, respectively).

Although the HBeAg seroconversion rates were significantly higher in patients with high pretreatment HBV DNA and serum ALT levels ( $p=0.005)$, no significant difference was observed in $\mathrm{HBs}$ Ag seroconversion rates in these patients. In addition, spontaneous seroconversion rates were not significantly different in patients with high serum ALT and HBV DNA levels ( $p>0.05$ ).

$\mathrm{HBeAg}$ reversion was observed only in 3 of the 5 male patients [mean age $6 \pm 3.3$ (range 3 -II) years] with cirrhosis, whereas HBsAg seroconversion was observed in none of them. One of the two patients in whom seroconversion was not observed had concurrent HCV infection. None of these children with cirrhosis developed HCC. One of the patients with cirrhosis died of liver-related causes, and one of them underwent liver transplantation during follow-up.

\section{DISCUSSION}

The development of chronic HBV infection is higher in individuals infected perinatally (90\%) or during childhood (20\%-30\%), which is thought to be due to immaturity of the immune system, than in adults $(<1 \%)(1,3)$. The most frequent mode of transmission is vertical transmission (from mother to child) in countries where moderate and high rates of HBsAg carriage are observed (I, 2). In our study, perinatally acquired HBV infection was observed in $60 \%$ of the patients. When compared with other transmission methods, no significant difference was observed in HBsAg and $\mathrm{HBeAg}$ seroconversion rates among patients who had vertical transmission of HBV.

Turkey is a moderate endemic area for HBV infection, and vaccination against hepatitis $B$ is recommended for infants, children, and adolescents since 1998 in routine vaccination programs; therefore, $94 \%$ of our patients were unvaccinated against HBV.

Factors associated with an increased risk of developing liver diseases and progression to cirrhosis include older age (>40 years), male sex, presence of $\mathrm{HBeAg}, \mathrm{HBV}$ genotype, mutations in the precore and core promoter regions of the viral genome, recurrent ALT flares, severity of fibrosis stage at presentation, HBV genotypes $C>B$ and $D>A$, and concurrent infections (HBV) $\mathrm{HCV}$ and/or HBV/HDV) (I). In the present study, a correlation was established between cirrhosis and initial HBsAg titer, fibrosis score, and coinfections with HDV and HCV. Male sex has been identified as an independent risk factor of cirrhosis (8). Molecular mechanisms between sex and fibrosis are unknown, but the antifibrogenic effect of estrogen has been proposed (9). 
TABLE 2. The association between seroconversion rates and clinical features and laboratory parameters

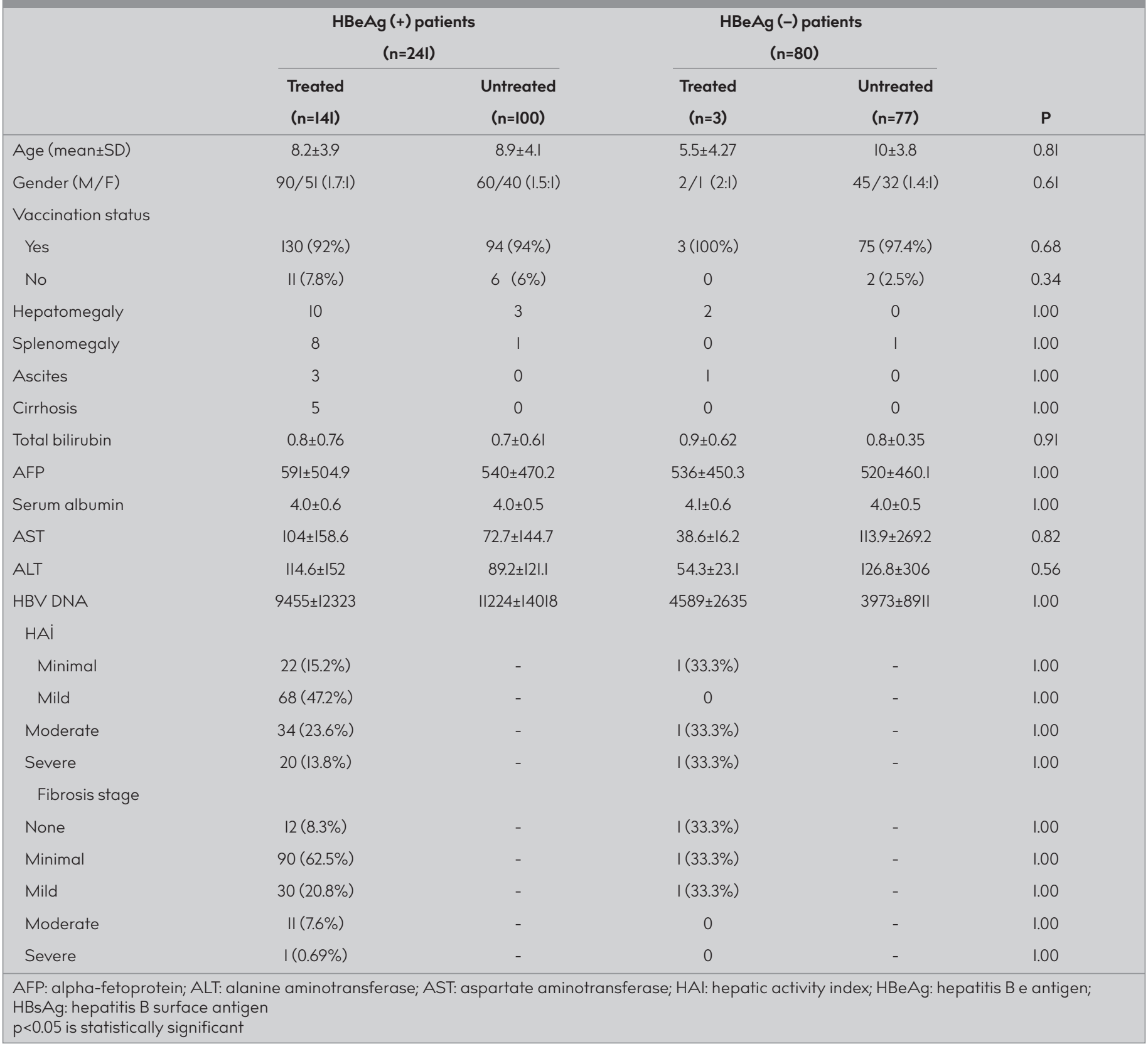

In our patients with $\mathrm{CHB}$ and all patients with cirrhosis, $61.4 \%$ were male patients.

Longitudinal studies have demonstrated that HBeAg seroconversion leads to the inactive HBsAg carrier state in most children (I, 4, 10-12). Spontaneous HBeAg and HBsAg seroconversion rates occur at an average rate of approximately $10 \%-16 \%$ and $0.6 \%-1 \%$ per year, respectively (I, 4, I0-13). Spontaneous HBeAg seroconversion rates have also been reported to be $<2 \%$ per year among children aged $\leq 3$ years and $4 \%-5 \%$ per year in older children (>3 years) (I3). In the present study, the spontaneous $\mathrm{HBeAg}$ seroconversion rate was $30.9 \%$ and spontaneous HBsAg seroconversion rate was $5.7 \%$, and these seroconversion rates did not change according to age.

Long-term follow-up studies of adult inactive HBsAg carriers have shown that infection in these patients rarely progresses to cirrhosis or HCC (14). Patients who clear HBeAg with sustained reduction of HBV DNA, ALT normalization, and eventually HBsAg loss have a very low risk of developing HCC and have increased survival compared with patients with cirrhosis and persistent high levels of HBV replication. Cirrhosis is infrequent, its incidence is estimated to be $3 \%-4 \%$ in cohort studies (II, I5), and it has been reported to be an early complication. Among the 5 patients with cirrhosis, 3 were aged $<4$ years.

Hepatitis B virus DNA and ALT levels persistently or intermittently increase in some patients who undergo HBeAg seroconversion. These patients have a naturally occurring mutant form of HBV that abolishes or down-regulates the HBeAg promoter region (4) and are redetermined as having $\mathrm{HBeAg}$-negative $\mathrm{CHB}$. Progression to $\mathrm{HBeAg}$-negative chronic hepatitis due to HBV variants not expressing HBeAg occurs at a rate of I-3 per 100 person-years following $\mathrm{HBeAg}$ seroconversion (2). These patients have the ability to significantly replicate HBV 
HBsAg-positive patients

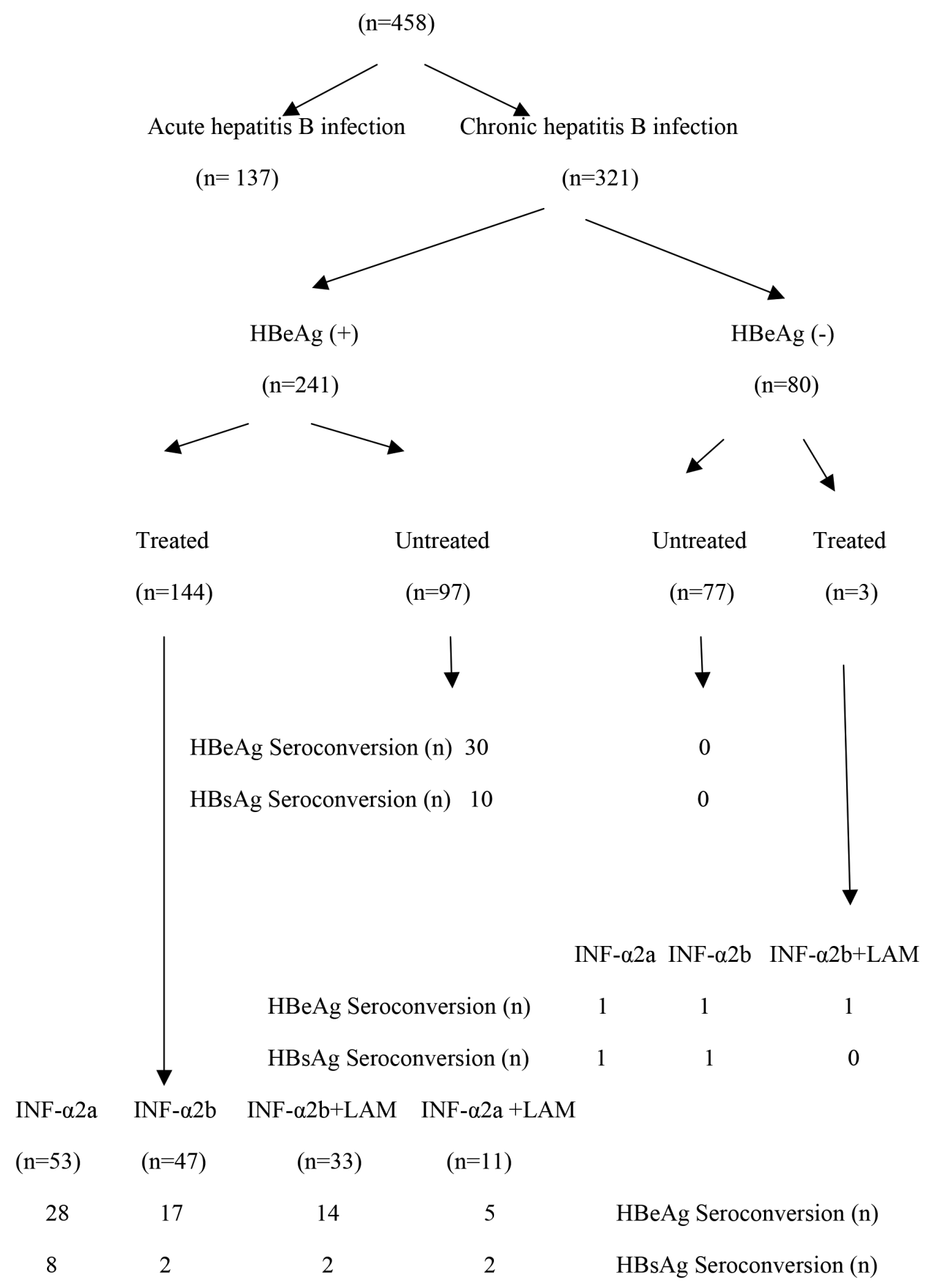

FIGURE I. Distribution of HBsAg-positive patients

in the presence of anti-HBe, even when ALT levels are normal. $\mathrm{HBeAg}$-negative $\mathrm{CHB}$ is not typically acquired as a de novo infection, although there is reportof transmission of precore mutant HBV (16). Sustained spontaneous remission is uncommon in patients with $\mathrm{HBeAg}$-negative $\mathrm{CHB}(6 \%-15 \%)$, and the longterm prognosis is poorer in $\mathrm{HBeAg}$-negative patients than in HBeAg-positive patients (16). In our study, 32.5\% of HBeAg-negative patients had HBV DNA positivity.
It has been reported that ALT is a poor predictor of outcomes and that IFN alone is not an appropriate indication for therapy $(3,17)$. The best predictors of adverse outcomes and treatment responses are HBV DNA levels in hepatitis B carriers (I, 17). ALT activity may be independently related to body mass index, sex, geographic origin, genotype, and abnormal lipid and carbohydrate metabolism, and ALT increases also occur during spontaneous HBeAg loss, in association with other viruses (I8). 


\begin{tabular}{|c|c|c|c|}
\hline $\begin{array}{l}\text { Treated patients } \\
(n=147)\end{array}$ & $\begin{array}{c}\mathrm{HBeAg} \\
\text { seroconversion }\end{array}$ & $\begin{array}{c}\mathrm{HBsAg} \\
\text { seroconversion }\end{array}$ & $\mathbf{p}$ \\
\hline $\begin{array}{l}\text { Interferon alfa- } 2 a \\
(n=54)\end{array}$ & $29(53.7 \%)$ & $9(16.6 \%)$ & 0.0001 \\
\hline $\begin{array}{l}\text { Interferon alfa- } 2 b \\
(n=48)\end{array}$ & $18(37.5 \%)$ & $2(4 \%)$ & 0.0001 \\
\hline $\begin{array}{l}\text { Interferon alfa } 2 b+\text { lamivudine } \\
(n=34)\end{array}$ & $15(44 \%)$ & $3(8.8 \%)$ & 0.002 \\
\hline $\begin{array}{l}\text { Interferon alfa-2a+lamivudine } \\
(n=I I)\end{array}$ & $5(45 \%)$ & $2(1.8 \%)$ & 0.36 \\
\hline$p<0.05$ is statistically significan & & & \\
\hline
\end{tabular}

Keeffe et al. (18) reported that higher seroconversion rates are observed in patients who have high pretreatment serum ALT and HBV DNA levels than the patients who have normal serum ALT and HBV DNA levels. In our study, higher HBeAg seroconversion rates were also observed in patients with high pretreatment serum ALT and HBV DNA levels than in other patients, but spontaneous seroconversion rates were not different in these patients than other patients.

The primary aim of antiviral therapy is the elimination and durable suppression of serum HBV DNA to the lowest levels possible (maximally $<10^{4}$ and preferably $<10^{3}$ ) and prevention of the progression of liver diseases to cirrhosis (17). It has also been reported that, compared with no antiviral therapy, antivirals improve the HBV DNA suppression and frequency of ALT normalization and $\mathrm{HBeAg}$ seroconversion in children with $\mathrm{CHB}$ (I8). IFN lacks resistance, is expensive, has to be administered via injections, and has many side effects such as flu-like symptoms, nausea, vomiting, anemia, autoimmune diseases, mood disorders, stroke and increased infections. Lamivudine is well tolerated, safe, and efficient, but it is also associated with high rates of resistance; therefore, it is not recommended as a first-line therapy in HBeAg-positive patients (19-23).

Fattovich et al. (15) and lorio et al. (24) reported that antiviral treatment does not significantly influence HBeAg clearance, whereas Komatsu et al. (25) reported that antiviral treatment can accelerate the achievement of $\mathrm{HBeAg}$ seroconversion in children. $\mathrm{HBeAg}$ seroconversion rates have been reported to be $76 \%-86 \%$ in treated patients and $37 \%-75 \%$ in untreated patients $(5,19)$. Although some trials have suggested that combination therapy with IFN alpha-2a and lamivudine results in higher rates of $\mathrm{HBe} A g$ seroconversion, HBV DNA undetectability, and ALT normalization than those obtained by treatment with lamivudine alone (26-28), some trials have suggested no benefit and advantages of combination therapy over treatment with IFN alone with respect to $\mathrm{HBeAg}$ seroconversion in accordance with our study $(29,30)$.

$\mathrm{HBeAg}$ seroconversion rates have been reported to be $16 \%-$ $40 \%$ with lamivudine treatment (3I-32). Keeffe et al. (19) compared seroconversion rates according to the given treatment (IFN and lamivudine) and found that $\mathrm{HBeAg}$ seroconversion rates are $18 \%$ with INF and $16 \%-18 \%$ with lamivudine and that
HBsAg seroconversion rate is $11 \%-25 \%$ with IFN. When compared, our seroconversion rates were higher at $46 \%$ with IFN alone and $44 \%$ with combined therapy with respect to $\mathrm{HBeAg}$ seroconversion. HBsAg seroconversion rates were similar at $10.7 \%$ with IFN alone and $11.1 \%$ with combined therapy. In our study, although the highest seroconversion rate was obtained with IFN alpha-2a treatment alone ( $n=29,53.7 \%, p=0.000 \mathrm{I})$, it is thought that it would not be used as a single agent in the treatment of $\mathrm{CHB}$ because of antiviral drug resistance. There was no difference in HBsAg seroconversion rates and seroconversion times between treated and untreated patients in our study.

It has been reported that the progression of liver diseases, perinatal transmission, and response to antiviral drugs may be influenced by genotypes (3). Keeffe et al. (19) recommended that patients should be routinely genotyped to help identify patients who may be at a greater risk for disease progression, particularly those who are the most appropriate candidates for treatment with IFN. The limitation of our study was that viral genotyping and sequence analysis were unavailable at our hospital.

In conclusion, a total of $30.9 \%$ patients underwent spontaneous $\mathrm{HBeAg}$ seroconversion and the spontaneous HBsAg seroconversion rate was $5.7 \%$. No significant difference was observed between treated and untreated patients with respect to seroconversion rates and seroconversion times. Further well-designed prospective studies are needed to clarify the natural course of $\mathrm{CHB}$ and predictors of disease progression, such as HBV genotypes, mutants, and viral load, for improving the management of children with $\mathrm{CHB}$.

Ethics Committee Approval: Authors declared that the research was conducted according to the principles of the World Medical Association Declaration of Helsinki "Ethical Principles for Medical Research Involving Human Subjects", (amended in October 2013).

Informed Consent: Written informed consent was obtained from the parents of the patients who participated in this study.

Peer-review: Externally peer-reviewed.

Author contributions: Concept - N.U.; Design - N.U., D.K.; Supervision N.U.;Resource - N.U.; Materials - N.U., D.K.; Data Collection and/or Processing - N.U., D.K.; Analysis and/or Interpretation - N.U., D.K.; Literature Search - D.K.; Writing - D.K., N.U.; Critical Reviews - N.U.

Conflict of Interest: The authors have no conflicts of interest to declare.

Financial Disclosure: The authors declared that this study has received no financial support.

\section{REFERENCES}

I. Fattovich G, Bortolotti F, Donato F. Natural history of chronic hepatitis B: Special emphasis on disease progression and prognostic factors. J Hepatol 2008; 48: 335-52. [CrossRef]

2. de Francis R, Hadengue A, Lau G, Lavanchy D, Lok A, Mclntyre N, et al. EASL International Consensus Conference on Hepatitis B 2002 Geneva,Switzerland Consensus statement. J Hepatol 2003; 39: P325. [CrossRef]

3. Jonas MM, Block JM, Haber BA. Treatment of children with chronic hepatitis $B$ virus infection in the United States: Patient selection and therapeutic options. Hepatology 2010; 52: 2192-205. [CrossRef] 
4. Mendy ME, McConkey SJ, Sande van der MAB, Crozier S, Kaye S, Jeffries, et al. Changes in viral load and $\mathrm{HBs} A g$ and $\mathrm{HBeAg}$ status with age in HBV chronic carriers in The Gambia. Virol J 2008; 5: I-8. [CrossRef]

5. Marx G, Martin SR, Chicoine JF, Alvarez F. Long-term follow-up of chronic hepatitis $B$ virus infection in children of different ethnic origins. J Infect Dis 2002; 186: 295-30I. [CrossRef]

6. Jonas MM. Hepatitis B virüs infection in children. Clin Liver Dis (Hoboken) 20I3; 2: 4I-4. [CrossRef]

7. Knodell RG, Ishak KG, Black WC,Chen TS, Craig R, Kaplowitz N, et al. Formulation and application of a numerical scoring system for assessing histological activity in asymptomatic chronic active hepatitis. Hepatology 1981; I: 43I-5. [CrossRef]

8. Iloeje UH, Yang HI, Su J, Jen CL, You SL, Chen CJ. Risk Evaluation of Viral Load Elevation and Associated Liver Disease/Cancer-In HBV (the REVEAL-HBV) Study Group. Predicting cirrhosis risk based on the level of circulating hepatitis B viral load Gastroenterology 2006; 130: 678-86. [CrossRef]

9. Shimizu I. Impact of oestrogens on the progression of liver disease. Liver Int 2003; 23: 63-9. [CrossRef]

10. Ni YH, Chang MH, Chen PJ, Tsai KS, Hsu HY, Chen HL, et al. Viremia profiles in children with chronic hepatitis $B$ virus infection and spontaneous e antigen seroconversion. Gastroenterology 2007; 132: 2340-5. [CrossRef]

II. Bortolotti F, Guido M, Bartolacci S, Cadrobbi P, Crivellaro C, Noventa $\mathrm{F}$, et al. Chronic hepatitis $\mathrm{B}$ in children after e antigen seroclearance: Final report of a 29-year longitudinal study. J Hepatol 2006; 43: 556-62. [CrossRef]

12. D'Antiga L, Aw M, Atkins M, Moorat A, Vergani D, Mieli-Vergani G. Combined lamivudine/interferon-alpha treatment in "immunotolerant" children perinatally infected with hepatitis B: a pilot study. J Pediatr 2006; 148: 228-33. [CrossRef]

13. Mieli-Vergani $G$, Vergani D. Treatment of hepatitis B virus in children. Why, whom, how? Indian J Gastroenterol 2006; 25: 12I-4.

14. Chang MH. Hepatitis B virus infection. Semin Fetal Neonatal Med 2007; 12: 160-7. [CrossRef]

15. Fattovich G. Natural history and prognosis of hepatitis B. Semin Liver Dis 2003; 23: 47-58. [CrossRef]

16. Hadziyannis SJ. Hepatitis B e antigen negative $C$ hepatitis B: from clinical recognition to pathogenesis and treatment. Viral Hep Rev 1995; I: 7-36.

17. Sherman M. Predicting survival in hepatitis B. Gut 2005; 54: 1521-3. [CrossRef]

18. Jonas MM, Lok ASF, McMahon BJ, Brown RS, Wong JB, Ahmed $A T$, et al. Antiviral therapy in management of chronic hepatitis $B$ viral infection in children: A systematic review and meta-analysis. Hepatology 2016; 63: 307-I8. [CrossRef]

19. Keeffe EB, Dieterich DT, Han SH, Jacobson IM, Martin P, Schiff ER, et al. A treatment algorithm for the management of chronic hepatitis
B virus infection in the United States: an update. Clin Gastroenterol Hepatol 2006; 4: I-27. [CrossRef]

20. Sokal EM, Paganelli $M$, Wirth $S$, Socha $P$, Vairo $P$, Lacaille $F$, et al Management of chronic hepatitis B in childhood: ESPGHAN clinical practice guidelines: consensus of an expert panel on behalf of the European Society of Pediatric Gastroenterology, Hepatology and Nutrition. J Hepatol 2013; 59: 8|4-29. [CrossRef]

21. Della Corte C, Nobili V, Comparcola D, Cainelli F, Vento S. Management of chronic hepatitis B in children: an unresolved issue. J Gastroenterol Hepatol 2014; 29: 912-9. [CrossRef]

22. Shah U, Kelly D, Chang MH, Fujisawa T, Heller S, González-Peralta $\mathrm{RP}$, et al. Management of chronic hepatitis B in children.J Pediatr Gastroenterol Nutr 2009; 48: 399-404. [CrossRef]

23. Komatsu H, Inui A, Fujisawa T. Pediatric hepatitis B treatment. Ann Transl Med 20I7; 5: 37. [CrossRef]

24. Iorio R, Tufano M, Giagnorio MG, Spagnuolo Ml, Giannattasio A. What evidence exists to support antiviral treatment in children with chronic hepatitis B? Antivir Ther 2014; 19: 225-7. [CrossRef]

25. Komatsu H, Inui A, Sogo T, Tsunoda T, Fujisawa T. Chronic hepatitis $B$ virus infection in children and adolescents in Japan. J Pediatr Gastroenterol Nutr 2015; 60: 99-I04. [CrossRef]

26. Popalis $C$, Yeung LTF, Ling SC, Ng V , Roberts EA. Chronic hepatitis $B$ virus (HBV) infection in children:25 years experience. J Viral Hepat 2013; 20: 20-6. [CrossRef]

27. Selimoglu MA, Ertekin $\mathrm{V}$, Karabiber $\mathrm{H}$. Treatment results of chronic hepatitis B in children: a retrospective study. Turk J Pediatr 20I0; 52: 360-6.

28. Barbaro G, Zechini F, Pellicelli AM, Francavilla R, Scotto G, Bacca $D$, et al. Long-term efficacy of interferon alpha-2b and lamivudine in combination compared to lamivudine monotherapy in patients with chronic hepatitis B: an Italian multicenter randomized trial (abstr). Hepatology 200I; 34: 318A. [CrossRef]

29. Schalm S, Heathcote J, Cianciara J, Farrell G, Sherman M, Willems $B$, et al. Lamivudine and alpha interferon combination treatment of patients with chronic hepatitis B infection:a randomised trial. Gut 2000; 46: 562-8. [CrossRef]

30. Lau GK, Piratvisuth T, Luo KX, Marcellin P, Thongsawat S, Cooksley $G$, et al. Peginterferon Alfa-2a, lamivudine, and the combination for $\mathrm{HBeAg-positive} \mathrm{chronic} \mathrm{hepatitis} \mathrm{B.} \mathrm{N} \mathrm{Engl} \mathrm{J} \mathrm{Med} \mathrm{2005;} \mathrm{352:} \mathrm{2682-}$ 95. [CrossRef]

31. Marcellin P, Lau GK, Bonino F, Farci P, Hadziyannis S, Jin R, et al. Peginterferon alfa-2a alone, lamivudine alone, and the two in combination in patients with $\mathrm{HBeAg}$-negative chronic hepatitis B. N Engl J Med 2004; 35I: 1206-17. [CrossRef]

32. Jonas MM, Kelly D, Mizerski J, Badia I, Areias J, Schwarz K, et al Clinical trial of lamivudine in children with chronic hepatitis B. N Engl J Med 2002; 346: 1706-I3. [CrossRef] 